\title{
MODEL PEMBELAJARAN PENDIDIKAN AGAMA ISLAM TERPADU DI SMA-IT DARUL HIKAM BANDUNG
}

\author{
Suprapto \\ Puslitbang Pendidikan Agama dan Keagamaan | Balitbang dan Diklat Kemenag RI \\ Jl. MH Thamrin No.06 Jakarta Pusat | Email: Puslitbangpenda@yahoo.co.id
}

\begin{abstract}
Integrated learning is a learning approach which involves multiple course subjects in order to provide meaningful experience to the students. Integrated education can be realized through the formulation of the vision and mission from the school that need to be achieved, school's objectives and programs (the strategic plan of the school), the formation of institution culture that reflects the blend of values and learning, which is operationally in the form of curriculum and extra-curriculum plan that formulated such a way so that the fundamental values of Islamic teaching and the science (general education) are integrated coherently. The implementation of integrated PAI learning in Darul Hikam Senior High School is clearly seen on the typical curriculum (kurhas) of character education with developing 7 values (sincere, patient, trustworthy, discipline, caring, smart and good deeds) through Taqwa Character Building (TCB) as mentioned above. This TCB is in line with the philosophy and vision built by Darul Hikam Senior High School. Moreover, TCB is also aligned with the objectives of the national education.
\end{abstract}

Keywords: Integrated PAI learning, Integrated Islamic School

\begin{abstract}
Abstrak
Pembelajaran terpadu sebagai pendekatan pembelajaran yang melibatkan beberapa mata pelajaran untuk memberikan pengalaman yang bermakna kepada siswa. Pendidikan terpadu dapat diwujudkan melalui perumusan visi dan misi dari sekolah yang ingin dicapai, tujuan dan program sekolah (rencana strategis sekolah), pembentukan institution culture yang mencerminkan perpaduan antara nilai dan pembelajaran, yang secara operasional berbentuk rancangan kurikulum dan ekstra kurikulum yang diramu sedemikian rupa sehingga nilai-nilai fundamental ajaran agama Islam dan ilmu terpadu (pendidikan umum) terpadu secara koheren. Implementasi pembelajaran PAI terpadu di SMA Darul Hikam terlihat jelas pada kurikulum khas (kurhas) pendidikan karakter dengan mengembangkan 7 nilai (ikhlas, sabar, amanah, disiplin, peduli, cerdas, dan ihsan) melalui Taqwa Character Building (TCB) sebagaimana disinggung di atas. TCB ini sejalan dengan falsafah dan visi yang dibangun oleh SMA Darul Hikam. Lebih dari itu, TCB juga selaras dengan tujuan pendidikan nasional.
\end{abstract}

Keywords: Pembejaran PAI Terpadu, Sekolah Islam Terpadu

\section{PENDAHULUAN}

Hakekat tujuan pendidikan nasional adalah menghasilkan manusia Indonesia seutuhnya, yaitu manusia yang beriman dan bertaqwa kepada Tuhan Yang maha Esa, beraklak mulia, sehat, berilmu, cakap, kretaif, mandiri, dan menjadi warga Negara yang demokratis serta bertanggungjawab (UU No. 20 Tahun 2003 tentang Sistem Pendidikan Nasional, Pasal 3). 
Pendidikan sudah selayaknya memberikan warna dan makna terhadap masyarakat. Oleh karena itu lembaga pendidikan harus berakar pada masyarakat setempat, memperhatikan ide-ide masyarakat setempat, memanfaatkan fasilitas yang ada di lingkungannya, serta menyesuaikan diri terhadap lingkungan setempat. Sementara itu lembaga pendidikan seharusnya juga berusaha meningkatkan cara hidup dan kehidupan masyarakat, dengan cara memberikan penerangan dan menciptakan bibit unggul.

Permasalahan pendidikanagamadisekolah umum pada saat ini sangat komplek, kenyataan menunjukkan bahwa hasil pendidikan agama Islam di sekolah umum kurang membawa hasil sebagaimana yang diharapkan. Untuk menjawab persoalan tersebut salah satu upaya yang dilakukan masyarakat yaitu dengan menghadirkan sekolah Islam terpadu. Sekolah ini akan mengintegrasikan pendidikan agama dengan sistem pendidikan sekolah yang karena keunggulannya banyak diminati oleh masyarakat. Keunggulan di sini dapat dilihat dari tiga sisi. Pertama, lembaga pendidikan yang unggul dalam penguasaan ilmu pengetahuan umum. Hal ini biasanya diukur dari seberapa banyak lulusannya berhasil masuk ke Perguruan Tinggi Negeri, atau sekolahsekolah favorit. Kedua, diukur dari tingkat keberagamaannya. Ketiga, adalah diukur dari sisi keunggulannya dalam mempersiapkan peserta didiknya menjadi insan yang beriman dan taqwa, serta mampu untuk hidup mandiri dalam masyarakat.

Permasalahannya adalah apa dan bagaimana pola pengintegrasian pendidikan agama Islam ke dalam sistem pendidikan sekolah yang berlangsung dan dikembangkan pada sekolahsekolah Islam terpadu?

Dengan demikian, berdasarkan latar belakang dan rumusan permasalahan tersebut, maka tujuan penelitian ini adalah untuk mengetahui pola pengintegrasian pendidikan agama Islam ke dalam sistem pendidikan pada sekolah-sekolah Islam terpadu. Penerima
Manfaat dari Kegiatan penelitian ini Direktorat Pendidikan Agama Islam pada Sekolah (Ditpais), Direktorat Jenderal Pendidikan Islam Kementerian Agama, serta stakeholders lainnya yang berkaitan dengan penyelenggaraan pendidikan agama dalam rangka meningkatkan mutu pendidikan agama di sekolah dengan menerapkan model penyelenggaraan pendidikan agama yang terintegrasi dalam sistem pendidikan di sekolah.

\section{Kerangka Konseptual}

\section{Pengertian Integrasi}

Integrasi berasal dari bahasa Inggris, integration, yang artinya terpadu. Menurut Sanusi, integrasi adalah suatu kesatuan yang utuh, tidak terpecah belah dan bercerai berai (terpadu). ${ }^{1}$ Dalam pengertian tersebut, pendidikan agama merupakan bagian yang tidak terpisahkan dari pendidikan umum, begitupun sebaliknya, sehingga ada saling terpadu, saling mengisi dan memperkuat satu dengan yang lain. Dalam tataran konseptual pendidikan, menurut Barbara Clark, bahwa pendidikan integratif atau pendidikan terpadu merupakan pendidikan yang mengupayakan pengoptimalan perkembangan peserta didik pada fungsi potensi kognitif, afektif, dan psikomotorik, dan membentuk peserta didik menjadi makhluk individual yang sekaligus juga sebagai makhluk sosial yang lebih kooperatif. ${ }^{2}$

Dengan demikian, pendidikan integratif atau pendidikan terpadu dapat diwujudkan melalui perumusan visi dan misi dari sekolah yang ingin dicapai, tujuan dan program sekolah (rencana strategis sekolah), pembentukan institution culture yang mencerminkan perpaduan antara nilai dan pembelajaran, yang secara operasional berbentuk rancangan

${ }^{1}$ Sanusi, S., (1997): Integrasi Umat Islam, PT. Iqomatuddin, Bandung, P.

${ }^{2}$ Barbara Clark, (1983): Integrative Education, New York, Publishing House, P. 
kurikulum dan ekstra kurikulum yang diramu sedemikian rupa sehingga nilai-nilai fundamental ajaran agama Islam dan ilmu terpadu (pendidikan umum) terpadu secara koheren. Bisa juga pendidikan integrasi atau pendidikan terpadu dibentuk melalui penciptaan lingkungan fisik yang berbasis iptek dan imtak, seperti adanya sarana rumah ibadah, laboratorium pendidikan agama, perpustakaan pendidikan agama islam, Dengan demikian, ada tiga kemungkinan integrasi yang diaplikasikan di sekolah Islam terpadu. Pertama, pendidikan agama Islam menyatu dalam kurikulum yang diterapkan sekolah, sebagai bagian yang tidak terpisahkan dan menyatu di dalam semua bagian keseluruhan kurikulum. Kedua, pendidikan agama Islam di integrasikan ke dalam keseluruhan kehidupan sekolah sebagai bagian budaya sekolah (membangun nuansa keagamaan yang kental di sekolah). Dan, ketiga, hanya sebagai pembelajaran yang berlangsung di kelas, sedangkan mata pelajaran lainnya sifatnya hanya mendukung pencapaian tujuan pendidikan agama Islam.

\section{Pembelajaran Terpadu}

Pembelajaran terpadu sebagai suatu konsep dapat diartikan sebagai pendekatan pembelajaran yang melibatkan beberapa mata pelajaran untuk memberikan pengalaman yang bermakna kepada siswa. Fokus perhatian pembelajaran terpadu terletak pada proses yang ditempuh siswa saat berusaha memahami isi pembelajaran sejalan dengan bentuk-bentuk keterampilan yang harus dikembangkannya. ${ }^{3}$ Berdasarkan hal tersebut, maka pengertian pembelajaran terpadu dapat dilihat sebagai:

1. Pendekatan pembelajaran yang menghubungkan berbagai mata pelajaran yang mencerminkan dunia nyata di sekeliling serta dalam rentang kemampuan dan perkembangan anak.

${ }^{3}$ Aminuddin 1994, Pembelajaran Terpadu sebagai Bentuk Penerapan Kurikulum 1994 Mata Pelajaran Bahasa dan Sastra Indonesia, FPBS IKIP Malang, h. 17
2. Cara untuk mengembangkan pengetahuan dan keterampilan anak secara serempak (simultan).

3. Merakit atau menggabungkan sejumlah konsep dalam beberapa mata pelajaran yang berbeda.

Pembelajaran terpadu merupakan suatu pendekatan yang berorientasi pada praktek pembelajaran yang sesuai dengan kebutuhan perkembangan anak. Pelaksanaan pendekatan pembelajaran terpadu bertolak dari sutau topik atau tema yang dipilih dan dikembangkan oleh guru bersama-sama dengan anak. Tujuan dari tema ini untuk menguasai konsep-konsep dari mata pelajaran terkait dijadikan sebagai alat dan wahana untuk mempelajari dan menjelajahi topik atau tema tersebut.

\section{Prinsip-Prinsip Pembelajaran Terpadu}

Dalam proses penggalian tema-tema perlu diperhatikan prinsip-prinsip sebagai berikut: (1) Dapat digunakan dengan mudah untuk memadukan mata pelajaran, (2) dapat memberikan bekal siswa bagi siswa untuk belajar selanjutnya, (3) disesuaikan dengan tingkat perkembangan siswa, (4) mampu menunjukkan sebagian besar minat siswa, (5) mempertimbangkan peristiwa-peristiwa nyata yang terjadi di dalam rentang waktu belajar, (6) mempertimbangkan kurikulum yang berlaku serta harapan masyarakat, (7) mempertimbangkan ketersediaan sumber belajar.

Dalam proses pelaksanaan pembelajaran terpadu perlu diperhatikan prinsip-prinsip sebagai berikut: (1) guru tidak bersikap otoriter yang mendominasi dalam proses pembelajaran, (2) pemberian tanggung jawab individu dan kelompok harus jelas, (3) guru bersikap akomodatif terhadap ideide yang terkadang tidak terpikirkan dalam perencanaan pembelajaran.

Dalam proses penilaian pembelajaran terpadu perlu diperhatikan prinsip-prinsip 
sebagai berikut: (1) memberi kesempatan siswa untuk melakukan penilaian diri, (2) guru perlu mengajak siswa untuk menilai perolehan belajar sesuai kriteria keberhasilan kompetensi yang disepati. ${ }^{4}$

\section{Sekolah Islam Terpadu}

Sekolah Islam Terpadu yang berkembang di masyarakat meliputi semua jenjang pendidikan, yaitu mulai dari sekolah dasar (SD IT), sekolah menengah pertama (SMP IT), sampai sekolah menengah atas (SMA IT). Sebagian sekolah tersebut melabeli dengan sebutan Islam Terpadu (IT), namun ada juga yang tanpa melabeli dengan tulisan IT, kendati di dalam penyelenggaraan pendidikannya melaksanakan pengintegrasian pendidikan agama ke dalam semua aspek pendidikan. Sekolah Islam Terpadu pada sejatinya adalah sekolah yang mengimplementasikan konsep pendidikan Islam berlandaskan pada al-Qur'an dan as-Sunnah.Dalamaplikasinya,SekolahIslam Terpadu dapat diartikan sebagai sekolah yang menerapkan pendekatan penyelenggaraan pendidikannya dengan memadukan pendidikan agama Islam dengan pendidikan umum (pengintegrasian) menjadi jalinan kurikulum tersendiri, keterpaduan dalam metode pembelajaran, dengan menekankan keseimbangan pada ranah kognitif, afektif, dan psikomotorik, serta membangun koordinasi, konsultasi, dan sinkronisasi antara sekolah, keluarga atau orang tua, dan masyarakat. Hal ini untuk mengaktifkan fungsi keluarga dan masyarakat dalam pengembangan potensi peserta didik, yang kebanyakan yang terjadi pada sebagian besar sekolah adalah beban terbesar pembinaan peserta didik adalah pada sekolah, sedangkan masyarakat, terutama sekolah seakan-akan berlepas tangan, bahkan menyerahkan sepenuhnya kewenangan tugas pendidikannya kepada sekolah.

${ }^{4}$ Konsep dasar dan Model-model Pembelajaran Terpadu 2013, anything-go-anything.blogspot.com/ 2013/11/konsep-dasar dan model-model. Html.
Pendapat lainnya mengatakan, bahwa Sekolah Islam Terpadu menawarkan satu model sekolah alternatif yang mencoba menerapkan pendekatan penyelenggaraan pendidikan yang memadukan pendidikan agama Islam dengan pendidikan umum, di mana semua mata pelajaran berada dalam kemasan ajaran dan nilai-nilai agama Islam. Dari beberapa pengertian di atas, dapat ditarik kesimpulan bahwa Sekolah Islam Terpadu adalah sekolah yang diselenggarakan dengan memadukan secara integratif ajaran dan nilai-nilai luhur agama Islam dalam struktur kurikulum dengan menggunakan pendekatan pembelajaran efektif dan efisien, yang mengedepankan keseimbangan pencapaian aspek kognitif, afektif, dan psikomotorik melalui pelibatan yang optimal dan kooperatif (koordinatif, konsultatif, sinkronisasi) antara sekolah (terutama guru), keluarga (orang tua), dan masyarakat dalam membangun karakter dan kompetensi yang harus dimiliki peserta didik.

\section{Metodologi Penelitian}

Penelitian ini merupakan penelitian kualitatif, makainstrumen pengumpulan data adalah peneliti itu sendiri. Peneliti dibekali dengan instrumen berupa pedoman pengumpulan data lapangan. Penelaahaan setiap topik permasalahan dilakukan secara holistik, sehingga dapat secara jelas mendeskripsikan fenomenafenomena yang diamati. Obyek yang menjadi sasaran penelitian ini adalah sekolah Islam terpadu yang tentunya dipilih sekolah yang mengindikasikan adanya aplikasi secara jelas pengintegrasian pendidikan agama Islam ke dalam sistem pendidikan sekolah. Adapun sekolah yang dijadikan sasaran adalah Sekolah Menengah Atas (SMA IT) Darul Hikam Bandung Jawa Barat. 


\section{HASIL DAN PEMBAHASAN}

\section{Gambaran Umum SMA-IT Al-Hikam}

\section{Sejarah Pendirian}

SMA IT Darul Hikam beralamat di Jl. Tubagus Ismail Depan No. 78 Bandung 40135 dengan NSS: 30. 2. 02. 60. 048. Ia berlokasi di Kelurahan Sekeloa, Kecamatan Coblong, Kota Bandung, Provinsi Jawa Barat. ${ }^{5}$ Tak jauh dari sekolah ini, terdapat Sekolah Tinggi Ilmu Komputer (STIKOM) dan Institut Teknologi Bandung (ITB). Kini SMA IT Darul Hikam di bawah kepemimpinan (Kepala Sekolah) Dr. H. Nandang Koswara, M.Pd.

Pendirian SMA IT Darul Hikam tidak dapat dilepaskan dari Yayasan Darul Hikam. Cikal bakal Yayasan Darul Hikam pada mulanya dirintis oleh KH. E. Hasbullah Hafidzi pada tahun 1942 setelah beliau menyelesaikan belajar di Pesantren Al-Lanah Cianjur. Yayasan ini pertama kali menyelenggarakan Madrasah Islam di Kampung Cisitu Girang (sekarang Jalan Cisitu Indah belakang Bapeda Jawa Barat, Kota Bandung). Madrasah ini sempat terhenti pada saat revolusi fisik karena rakyat harus mengungsi meninggalkan Bandung. Namun, pada tahun 1949, setelah kembali dari pengungsian, madrasah ini dibuka kembali dan dinaikkan statusnya menjadi Sekolah Dasar Islam dengan sebutan Sekolah Rakyat Muslimin. ${ }^{6}$

Pada tahun 1951, sekolah ini sudah memiliki bangunan sendiri di atas lahan pinjaman dari Ustadz Abdussalam. Pada tahun 1953, yayasan ini terus berkembang sehingga kegiatan pendidikan ditingkatkan dengan membuka sekolah tingkat SMP dengan waktu belajar pada siang hari. Dalam waktu tak terlalu lama SMP tersebut akhirnya dipindahkan ke Jalan Puyuh No. 5 dengan sebutan SMP Muslimin. ${ }^{7}$

\footnotetext{
${ }^{5}$ Lihat "Profil Yayasan Darul Hikam", h. 4.

${ }^{6}$ Dikutip dari "Profil Yayasan Darul Hikam”, hal. 4.

7 "Profil Yayasan ... h. 4.
}

Dalam proses pertumbuhannya, Yayasan Darul Hikam tidak berjalan mulus. Ia menghadapi hambatan dan tantangan yang tidak ringan. Misalnya, pada tahun 1963, bangunan SD Islam yang berlokasi di Cisitu Girang mendapat musibah. Bangunan itu ambruk diterpa angin kencang, sehingga para murid dipindahkan ke sekolah-sekolah yang ada di sekitar lokasi itu. ${ }^{8}$

Karena bangunan SD Islam di Cisitu Girang itu hancur, maka perintisan dimulai kembali. Dan, pada tahun 1964 Taman Kanak-kanak Islam dibuka yang bertempat di rumah Hj. Dedeh Ruyanti Hasbullah, Jl. H. Juanda 212 Bandung. Sekolah ini bertahan sampai peristiwa pemberontakan G $30 \mathrm{~s} /$ PKI. Setelah pemberontakan G 30 S/PKI gagal, KH. E. Hasbullah Hafidzi berkeinginan keras untuk mempunyai masjid yang pada akhirnya berhasil membangun Masjid Darul Hikam berukuran $12 \mathrm{~m}$ x $8 \mathrm{~m}$ di Jl. Ir. H. Juanda 285. ${ }^{9}$ Setelah pembangunan masjid itu selesai, secara bertahap Yayasan Darul Hikam menyelenggarakan Pendidikan Formal yang berorientasi kepada Kurukulum Departemen Pendidikan Nasional seperti SMA IT Darul Hikam ini.

SMA Darul Hikam didirikan oleh Yayasan Darul Hikam pada tahun Pelajaran 1979/1980, dengan status Terdaftar Tahun 1984; status Diakui Tahun 1994; status Disamakan (sampai sekarang) Tahun 2005; terakreditasi A; Nomor Data Sekolah: B21064009; Nomor Statistik Sekolah: 30.2.02.60.06.048. ${ }^{10}$

Didirikannya SMA ini memiliki kekhasan pendidikan sekolah sebagai berikut: Pertama, konsep sekolah inti/sekolah kader. Jumlah siswa dibatasi maksimal 26 orang per kelas. Rasio guru: siswa = 1: 13. Kedua, Integrated and Holistic Islamic Education System di dalam tiga ranah pengembangan kognitif, afektif, dan psikomotor. ${ }^{11}$

\footnotetext{
8 "Profil Yayasan ... h. 4.

9 "Profil Yayasan ... h. 4.

${ }^{10}$ Dikutip dari “Profil Yayasan Darul Hikam”, h. 22.

11 "Profil Yayasan ... h. 22.
} 
Visi SMA Darul Hikam ialah "Menjadi sekolah Islam terbaik di Jawa Barat melalui budaya (jatidiri, ciri khas dan keunggulan) Berakhlak dan Berprestasi". ${ }^{12}$ sementara itu dengan visi tersebut SMA Darul Hikam mengembangkan misi sebagai berikut: ${ }^{13}$

1. Melaksanakan pendidikan Islam secara utuh, terpadu, dan sempurna untuk membangun Akhlaq Karimah siswa dan semua civitas akademika.

2. Melaksanakan pendidikan umum secara utuh, terpadu, dan sempurna untuk meraih prestasi siswa dan civitas akademika dalam berbagai bidang kependidikan.

3. Membangun citra baik sekolah Islam sebagai bagian dari sistem pendidikan nasional.

4. Membangun silaturahim dan kerja sama dengan orang tua dalam proses pendidikan Islam bagi putra/i mereka.

Tujuan didirikannya SMA Darul Hikam adalah: $^{14}$

1. Mengembangkan dan menciptakan penyelenggaraan proses pendidikan yang efektif berorientasikan pada kreatifitas, inovasi, dan prestasi ditandai dengan kehadiran siswa dan guru lebih dari $95 \%$.

2. Mengelola tenaga pendidikan dan tenaga kependidikan berdasarkan keterampilan dan profesionalisme ditandai dengan $100 \%$ guru menggunakan IT dalam proses pembelajaran yang dikemas dalam PSB (Pusat Sumber Belajar).

3. Meningkatkan pengetahuan dan kecakapan melalui belajar secara mandiri dalam rangka membangun ketahanan dan kebugaran jasmani dengan berdirinya dan terkelolanya 4 klub siswa.

12 Dikutip dari "Program Kerja SMA Darul Hikam Tahun Pembelajaran 2013/2014", h. 6.

13 "Program Kerja SMA ... h. 7.

14 “Program Kerja SMA ... h. 7-8.
4. Mengembangkan berfikir yang logis, kritis, inovatif dan kreatif dalam memecahkan masalah serta dapat berkomunikasi baik lisan maupun tulisan sesuai dengan konteksnya melalui berbagai media termasuk Teknologi Informasi dan Komunikasi ditandai dengan digunakannya media IT untuk komunikasi baik antar guru dengan siswa, maupun dengan orang tua.

5. Meningkatkan kualitas prestasi akademik dan non akademik dengan meningkatkan raihannilai UjianNasional, pencapaian KKM berkualitas dan fokus di ekstrakurikuler Paduan Suara dan Angklung.

6. Mengembangkan partisipasi seluruh warga sekolah dan masyarakat yang dilandasi rasa tanggung jawab dan dedikasi dengan terselenggaranya forum bersama antara sekolah dengan warga masyarakat.

7. Memberi kepuasan dan kenyamanan bagi warga sekolah dan masyarakat dengan terciptanya iklim kerja yang profesional.

\section{Struktur Organisasi}

SMA IT Darul Hikam di bawah Yayasan Darul Hikam. Struktur organisasi Yayasan Darul Hikam meliputi Dewan Pendiri/ Pembina, Dewan Pengawas, Dewan Pengurus, dan Dewan Pengembangan. Dewan Pengurus membawahi Majelis Da'wah, Majelis Pendidikan (Perguruan), dan Majelis Pengembangan Masyarakat. ${ }^{15}$ Majelis Da'wah membidangi Dewan Kemakmuran Mesjid (DKM), Divisi Pembinaan Majelis Ta'lim, Divisi Penerbitan, Lembaga Pengembangan Dakwah, KBIH, dan Perpustakaan umum. Majelis Pendidikan (Perguruan) membidangi Asrama/Pesantren, Taman Kanak-kanak I, Taman Kanak-kanak II, Sekolah Dasar I, Sekolah Dasar II, Sekolah Menengah Pertama, Sekolah Menengah Atas, Darul Hikam International School, Rumah Dana Pendidikan, SSA (Student Solution and Achievement [SSA] Darul Hikam), LP3KS (Lembaga Pelayanan

\footnotetext{
15 “Profil Yayasan ... h. 5.
} 
Psikologi dan Pengembangan Keluarga Sakinah), CEQU (Centre for Education and Human Resource Quality Improvement), dan Poliklinik Sekolah. Majelis Pengembangan Masyarakat membidangi Kantor Bantuan Hukum/Syariah, Koperasi Warga Darul Hikam, Lawazis (menjembatani para aghniya dalam memberdayakan dan menyalurkan zakat, infaq, dan sodaqoh), Lembaga Santunan Duafa, dan Desa Kampung Binaan. SMA IT Darul Hikam di bawah langsung Perguruan Darul Hikam. Adapun struktur organisasi SMA IT Darul Hikam Tahun Pembelajaran 2013/2014 meliputi Kepala Sekolah, Ka. Ur. Tata Usaha, PKS Kurikulum, PKS Sarana, PKS Kesiswaan, PKS Humas, Koordinator Mata Pelajaran dan MGMP, Wali Asuh, Bimbingan dan Konseling, Guru Mata Pelajaran, dan Siswa.

\section{Guru dan Tenaga Kependidikan}

Tenaga pengajar/guru di SMA IT Darul Hikam berjumlah 31 orang. Dari 31 orang tersebut yang berpendidikan pascasarjana berjumlah empat orang guru, yaitu 1 orang berpendidikan S3 jurusan Pendidikan Nilai; dan 3 orang lagi berpendidikan S2 Ilmu Peternakan, Pendidikan Seni Rupa, dan Profesi Psikologi. Dari status kepegawaian, terdapat 3 orang guru berstatus Pegawai Negeri Sipil (PNS). Selebihnya, mereka berstatus Guru Tetap Yayasan (GTY), Guru Honor Penuh (GHP) dan Guru Tidak Tetap (GTT). Pegawai non guru (tenaga kependidikan) berjumlah 7 orang. 3 orang tata usaha, 1 orang pustakawati, dan 3 orang karyawan. Mereka berlatar belakang pendidikan S1, D3, SMA, dan SMP. Dari status kepegawaian, mereka ada yang Karyawan Tetap Yayasan (KTY) dan ada juga yang Karyawan Tidak Tetap Yayasan (KTT).

\section{Keadaan Siswa dan Sarana Prasarana}

Siswa SMA IT Darul Hikam pada pembelajaran 2013-2014 seluruhnya berjumlah 295, dengan rincian kelas X berjumlah 119 orang dengan 4 kelas; kelas XI berjumlah 79 orang dengan 4 kelas; dan kelas XII berjumlah 98 orang dengan 4 kelas. ${ }^{16}$ Siswa umumnya berasal dari Bandung, Sumedang, Cikampek, Garut, Purwakarta, Tasikmalaya, Cianjur, Jakarta, dan Rangkas Bitung Banten. ${ }^{17}$ Pada umumnya latar belakang sosial ekonomi orang tua siswa SMA Darul Hikam Bandung berasal dari stratifikasi sosial kelas menengah ke atas. Hal ini tampak terlihat pada data siswa berikut orang tua dan pekerjaannya. ${ }^{18}$ Adapun latar belakang pendidikan orang tua siswa SMA Darul Hikam, Strata $1=67 \%$, Strata $2=22 \%$, Strata $3=11 \%$. Rekruitmen siswa SMA Darul Hikam Bandung dilakukan melalui Tes. Tes ini meliputi: (a) Psikotes; (b) Tes Akademik (Matematika, IPA, Bahasa Inggris), PAI; (c) Tes Membaca Al Qur'an; dan (d) Wawancara (menggali minat, dan memotret karakter siswa). ${ }^{19}$

Sementara itu pada aspek sarana dan prasarana yang dimiliki SMA Darul Hikam antara lain Lab IPA, Televisi, infocus, AC Lab Komputer, Televise 21 inch di Lab Bahasa, tape Lab Bahasa, fasilitas olah raga, penunjang ibadah, fasilitas kelas, dan perpustakaan.

\section{Implementasi Pembelajaran PAI Terpadu}

Beberapa hal yang melandasi dari pelaksanaan pembelajaran PAI terpadu di SMA Darul Hikam Bandung adalah:

\section{Falsafah (Ideologi Keagamaan dan Pendidikan)}

Falsafah (ideologi keagamaan dan pendidikan) SMA IT Darul Hikam adalah berakhlak dan berprestasi yang selalu mengedepankan nilai-nilai ke-Islaman yang berbasis pada AlQur'an dan Sunnah dalam setiap pengembangan kurikulum. Di sini Islam menjadi dasar/acuan bagi seluruh komponen satuan pendidikan di SMA Darul Hikam. Falsafah itu dijabarkan dalam sepuluh budaya berakhlak berprestasi,

${ }^{16}$ Lihat "Program Kerja SMA Darul Hikam Tahun Pembelajaran 2013/2014", h. 9.

${ }^{17}$ Lihat "Daftar Nama Siswa Kelas X, XI, dan XII SMA Darul Hikam Bandung Tahun Pembelajaran 2013-2014.

${ }^{18}$ Wawancara dengan Kepala Sekolah, 26 September 2013.

${ }^{19}$ Wawancara dengan Kepala Sekolah, 26 September 2013. 
yaitu:20 Rajin beribadah dan biasa shalat berjamaah, Disiplin dalam belajar/bekerja keras, Lingkungan bersih, hijau dan bebas rokok, Pergaulan Islami terutama antara pria dan wanita, Santun bertutur kata dan bersikap, Kompak dan peduli sesama kawan, Jujur dan bertanggung jawab terhadap tugas, Mandiri dan pelopor dalam kebajikan, Tradisi amar ma'mur nahyi munkar, dan Tradisi meraih prestasi dan juara.

\section{Dasar Sosial dan Budaya}

Yang menjadi latar belakang kelahiran sekolah ini di bawah langsung Yayasan Darul Hikam ialah adanya kegersangan beragama di kalangan masyarakat (Dago) sekitar karena melekatnya budaya komunis. Karena Dago menjadi basis komunis, maka nilai-nilai Islam tidak tumbuh di masyarakat tersebut. Untuk itu, kehadiran lembaga pendidikan yang menanamkan nilai-nilai Islam menjadi suatu kebutuhan. ${ }^{21}$ Berdirinya lembaga pendidikan ini terbukti memiliki pengaruh terhadap masyarakat sekitarnya. Mereka bersedia mengikuti program-program keagamaan yang diselenggarakan Darul Hikam sehingga kehidupan keagamaan menjadi semarak dan nilai-nilai Islam berkembang di tengah-tengah masyarakat.

\section{Konsep Kehidupan}

SMA Darul Hikam mengembangkan konsep kehidupan bagi guru dan siswa. ${ }^{22}$ Bagi guru, Pertama: peningkatan spiritual mereka; khususnya di lingkungan keluarga besar dengan pembinaan kehidupan keagamaan. Kedua, perhatian ekonomi. Hal ini antara lain diupayakan dengan adanya Jamsostek dan sertifikasi guru. Bagi siswa, dikembangkan soft skill; yaitu antara lain sikap keteguhan, kemandirian, dan kedisiplinan. Ujung tombak

20 "Program Kerja SMA ... ..., hal. 2; Wawancara dengan Kepala Sekolah, 26 September 2013.

${ }^{21}$ Wawancara dengan Kepala Sekolah, 26 September 2013.

${ }^{22}$ Wawancara dengan Kepala Sekolah, 26 September 2013. dari ini semua ialah bahwa guru harus selalu memperhatikan sikap keberagamaan siswa.

\section{Konsep Psikologi Pendidikan}

Konsep psikologi pendidikan yang dikembangkan SMA Darul Hikam berbasis psikologi agama. Artinya, sekolah tidak hanya menyelenggarakan bimbingan dan konseling dengan koordinator 1 orang sebagai wali asuh bagi semua kelas (X, XI, XII); tetapi juga bagaimana nilai-nilai agama dapat dilaksanakan secara holistik melalui Taqwa Character Building (ikhlas, sabar, amanah, disiplin, peduli, cerdas, dan ihsan). ${ }^{23}$

\section{Konsep Pendidikan}

Konsep pendidikan yang dibangun oleh SMA Darul Hikam ialah sekolah Islam yang berkualitas. Implementasinya menjadikan sekolah itu sebagai sekolah inti atau kader yang akan melahirkan kader-kader militan yang mumpuni, memiliki pengakuan akademis, dan kemuliaan akhlak. ${ }^{24}$

\section{Konsep Muatan Kurikulum}

Muatan kurikulum yang dikembangkan oleh SMA Darul Hikam ialah kurikulum khas (kurhas) pendidikan karakter atau disebut dengan Taqwa Character Building (ТСВ) dengan mengembangkan 7 nilai karakter taqwa, yaitu ikhlas, sabar, amanah, disiplin, peduli, cerdas, dan ihsan..$^{25}$ Tujuh nilai karakter taqwa/TCB itu diimplementasikan melalui internalisasi dalam semua mata pelajaran, mata pelajaran khas, dan kegiatan kesiswaan. ${ }^{26}$ Implementasi berupa internalisasi 7 nilai dalam semua mata pelajaran dimaksudkan agar terlaksananya 7 nilai TCB dalam aktivitas pembelajaran

\footnotetext{
${ }^{23}$ Wawancara dengan Kepala Sekolah, 26 September 2013.

${ }^{24}$ Wawancara dengan Kepala Sekolah, 26 September 2013.

${ }^{25}$ Wawancara dengan Kepala Sekolah, 26 September 2013; lihat pula "Kebijakan dan Program Kurhas Perguruan Darul Hikam Bandung", disampaikan pada Rapat Pimpinan Perguruan Darul Hikam Bandung, 22 Juni 2013.

${ }^{26}$ Dikutip dari "Kebijakan dan Program Kurhas Perguruan Darul Hikam Bandung”, disampaikan pada Rapat Pimpinan Perguruan Darul Hikam Bandung, 22 Juni 2013.
} 
dengan tujuan mendorong prestasi akademik siswa. Penanggungjawabnya adalah PKS Kurikulum/Pembina Bidang Akademik dengan pelaksana guru mata pelajaran. Ruang lingkup kegiatannya adalah KBM (intra), pemberian tugas (KO), dan evaluasi (ulangan/ujian). Implementasi berupa internalisasi 7 nilai dalam mata pelajaran khas (PAI [PAI (Diknas), Al-Qur'an, Mentoring, TKK), ICT, dan bahasa (conversation [Inggris] dan muhadastah [Arab]) dimaksudkan agar terlaksananya 7 nilai TCB dalam aktivitas pembelajaran dengan tujuan mencapai keunggulan dalam bidang PAI, ICT, dan bahasa. Penanggungjawabnya adalah PKS Kurikulum/Pembina Bidang Akademik dengan pelaksana guru mata pelajaran khas. Ruang lingkup kegiatannya adalah KBM (intra), pemberian tugas (KO), dan evaluasi (ulangan/ujian). Implementasi berupa internalisasi 7 nilai dalam kegiatan kesiswaan melalui 5 pilar kegiatan kesiswaan (SDM [siswa], wawasan dan motivasi, kepedulian, bakat minat, dan prestasi prestisius), pelatihan TCB, dan BBB dimaksudkan agar terlaksananya 7 nilai dalam kegiatan kesiswaan dengan tujuan lebih mengembangkan soft skill. Penanggungjawabnya adalah PKS Kesiswaan/ Pembina Bidang karakter dengan pelaksana wali asuh, pelatih TCB, dan pelatih Ekskul. Ruang lingkup kegiatannya adalah kegiatan di kelas, di luar kelas, dan luar sekolah.

\section{Program PAI Terpadu (dalam kelas, dan luar kelas)}

Program unggulan PAI terpadu di SMA Darul Hikam Bandung meliputi; Pertama, kajian tematik PAI melalui pembelajaran aktif, kreatif, inovatif, dan menyenangkan yang dikemas dalam Mentoring Wawasan Islam. Materi mentoring ini berbeda-beda untuk masing-masing kelas. Untuk siswa kelas $\mathrm{X}$ materinya antara lain: (1) husnudzon terhadap Allah dengan pokok bahasan doa yang tidak dikabulkan dengan target/tujuan memahami sebab doa tidak terkabul dan senantiasa baik sangka dalam setiap keadaan dalam kehidupan sehari hari; (2) husnudzon terhadap diri sendiri dengan pokok bahasan tidak putus asa terhadap rahmat Allah dengan target/tujuan meyakini dan sadar bahwa manusia berencana, Allah yang menentukan segala kejadian serta memiliki motivasi dan semangat pantang menyerah; (3) husnudzon terhadap sesama manusia dengan pokok bahasan melatih untuk berpikir positif dengan target/tujuan terbiasa dan mampu berpikir positif dalam menghadapi berbagai hal; (4) hukum dasar AlQuran dengan pokok bahasan Al-Quran sebagai sumber hukum pertama dengan target/ tujuan meyakini kebenaran Al-Qur'an sebagai way of life; (5) hukum dasar al-Hadist dengan pokok bahasan sanad dan matan hadits dan asal usul hadist dan macamnya (mutawatir, shohih, hasan dan dhoif) dengan target/tujuan memahami keshahihan al-hadits ditinjau dari periwayatan dan isi kandungan serta meyakini al-hadits sebagai perkataan, perbuatan serta taqrir Rasul SAW yang bersumber dari wahyu; dan lain-lain. ${ }^{27}$

Untuk siswa kelas XI materinya antara lain: (1) taubat dengan pokok bahasan kisah teladan dengan target/tujuan memahami makna taubat dan mengaplikasikan dalam kehidupan sehari-hari; (2) roja (harapan) dengan pokok bahasan kisah 3 orang yang terkurung dalam goa dengan target/tujuan memahami makna roja' dan mengaplikasikan dalam kehidupan sehari-hari; (3) muamalah 1 dengan pokok bahasan jual beli dan sewa menyewa secara syariah dengan target/ tujuan memahami hukum jual beli dan sewa menyewa secara syar'i dan hikmahnya; (4) muamalah 2 dengan pokok bahasan perbankan syariah dan konvensiaonal dengan target/ tujuan memahami perbedaan bank syari'ah dengan bank konvensional serta hikmah pelarangan riba dalam Islam; (5) muamalah 3 dengan pokok bahasan produk bank syariah (mudorobah, musyarokah) dengan target/ tujuan memahami produk-produk bank

${ }^{27}$ Wawancara dengan Kepala Sekolah, 26 September 2013; lihat pula "Materi Mentoring Siswa Kelas X SMA Darul Hikam Bandung Tahun Pembelajaran 2013/2014”.

EDUKASI Volume 12, Nomor 1, Januari-April 2014 
syariah serta mengaplikasikan dalam aktivitas ekonomi yang halal berlandaskan syari'ah; (6) menghargai orang lain 1 dengan pokok bahasan perbedaan suku, bahasa dan agama (perbandingan HAM internasional) dengan target/tujuan memahami HAM dalam tinjauan Islam dan hukum international; (7) menghargai orang lain 2 dengan pokok bahasan membajak hak cipta (lagu, film, karya ilmiah) dengan target/tujuan menjauhi perilaku plagiat dan mengambil hak orang lain tanpa izin; dan lainlain. ${ }^{28}$

Untuk siswa kelas XII materinya antara lain: (1) adil dengan pokok bahasan bedah profesi penegak hukum dengan target/tujuan memahami keadilan hukum dalam Islam dan implementasi adil dalam keseharian; (2) ridho dengan pokok bahasan syukur nikmat dengan target/tujuan memahami makna ridlo dan mengaplikasikan dalam kehidupan seharihari; (3) amal shaleh dengan pokok bahasan shadaqoh jariyah, ilmu yang bermanfaat, doa anak shaleh dengan target/tujuan mengaplikasikan 3 amal shaleh yang akan terus mengalir pahalanya sampai liang lahat dalam kehidupan sehari-hari; (4) munakahat dengan pokok bahasan nikah syariah, nikah siri, nikah kontrak, nikah dini dengan target/ tujuan memahami makna, tujuan dan hukum nikah; (5) perkembangan Islam 1 dengan pokok bahasan pergerakan dan organisasi Islam di IndonesiaA (MUHAMMADIYAH, NU, PERSIS, Syarikat Islam, PUI, Al Wasliyah ALIRSYAD) dengan target/tujuan memahami pergerakan Islam di Indonesia melalui ormas Islam; (6) perkembangan Islam 2 dengan pokok bahasan penyimpangan pergerakan Islam (NII KW 9, JIL, AHMADIYAH) dengan target/tujuan memahami penyimpangan dan pengkaburan makna pergerakkan Islam di Indonesia; (7) perkembangan Islam 3 dengan pokok bahasan Ikhwanul Muslimin, Hijbut Tahrir, HAMAS

28 "Materi Mentoring Siswa Kelas XI SMA Darul Hikam Bandung Tahun Pembelajaran 2013/2014". dengan target/tujuan memahami pergerakan Islam di dunia; dan lain-lain. ${ }^{29}$

Kedua, Tes Kecakapan Khusus Pendidikan Agama Islam (TKK PAI). TKK PAI merupakan salah satu lini kegiatan keagamaan yang dijadikan sebagai tolok ukur untuk mencapai target minimal; mulai dari Bintang I, II, III, IV, V, dan VI dengan penekanan pada praktek. Materi Bintang I, antara lain dapat melafalkan janji siswa dalam 3 bahasa, dapat menerangkan 20 sifat wajib dan mustahil bagi Allah SWT, dapat melafadzkan asmaul husna berikut artinya, dapat mempraktekkan adzan dan iqamah berikut doa setelah adzan, dapat mempraktekkan wudhu dan tayaum berikut doanya, dapat mempraktekkan shalat fardhu, dapat mempraktekkan doa dan dzikir setelah shalat fardhu, dapat memahami sumber hukum Islam, hukum Taklifi dan hikmah ibadah, dapat mempraktekkan shalat berjamaah dan shalat sunah, membiasakan diri dalam kegiatan tadzkiratun nafs di sekolah, dapat menjelaskan strategi dakwah Rasululllah SAW periode Mekkah dan Madinah, ayat pilihan, dan haifdzil Qur'an. ${ }^{30}$ Materi Bintang II, antara lain dapat mempraktekkan bentuk kepedulian sosial kepada kaum dhuafa melalui bakti sosial, dapat memahami pengertian haji dan zakat, dapat memahami makna dan 8 asnaf mustahiq, dapat berperan serta dalam penerimaan dan penyaluran zakat, infaq dan shadaqah, dapat memahami pelepasan dan perubahan harta dalam Islam, dapat berperan aktif dalam berbagai kegiatan di bulan Ramadhan, dapat menjelaskan strategi dakwah Rasulullah SAW periode Madinah (pasca Hijrah) dan Madinah, dapat menjelaskan dan menjauhi riba, ayat-ayat pilihan, dan hifdzil Qur'an. ${ }^{31}$ Materi Bintang III, antara lain dapat mempraktekkan penyembelihan hewan qurban untuk laki-laki, dapat menjelaskan

\footnotetext{
29 "Materi Mentoring Siswa Kelas XII SMA Darul Hikam Bandung Tahun Pembelajaran 2013/2014".

${ }^{30}$ Dikutip dari Koswara, Nandang dan Afiefah, Nawar, 2011, "Himpunan Materi TKK PAI Tes Kecakapan Khusus Pendidikan Agama Islam”, SMA Darul Hikam Bandung, h. v.

${ }^{31}$ Lihat "Himpunan Materi TKK PAI ...", h. v-vi.
} 
tata cara penyembelihan hewan qurban, dapat berperan serta pendistribusian hewan qurban pada daerah binaan, dapat menjelaskan 3 hikmah berqurban, dapat membiasakan berperilaku terpuji dengan memahami makna raja' dan taubat, dapat menjelaskan dan mempraktekkan perekonomian dalam Islam (muamalah), dapat menguraikan dengan sistematis tentang peran nabi Muhammad dalam mempersatukan suku 'Aus dengan Khajraj di Yatsrib (Madinah), ayat-ayat pilihan, dan hifdzil Qur'an. ${ }^{32}$ Materi Bintang IV, antara lain dapat mempraktekkan tata cara pengurusan jenazah, dapat menjadi khatib, imam, MC dan muadzdzin, dapat menuliskan dan memahami 5 ayat sajdah di anatar 15 ayat sajdah, dapat mengaplikasikan hadist tentang manfaatkan lima kesempatan sebelum datang limakesempatan, dapat mempraktekkan shaum sunnah Senin-Kamis, dapat mengaplikasikan 3 hijab pergaulan Islami antara pria dan wanita, dapat menjelaskan hukum bacaan nun mati/ tanwin, hifdzil Qur'an ayat pilihan, dan hifdzil Qur'an Juz 'Amma. ${ }^{33}$ Materi Bintang V, antara lain dapat memahami tata cara munakahat dalam Islam dan hikmahnya, dapat memahami konsepsi Islam tentang perceraian, rujuk dan hikmahnya, dapat memahami hukum pidana Islam, dapat menuliskan masing-masing 5 ayat Al-Qur'an yang berkaitan dengan surga dan neraka, hifdzil Qur'an ayat pilihan, dan hifdzil Qir'an Juz 'Amma. ${ }^{34}$ Materi Bintang VI, antara lain dapat menghimpun 25 kliping dari berbagai sumber yang berkaitan dengan aliran sesat di dunia, dapat menerangkan 3 hikmah diturunkannya Al-Qur'an secara berangsurangsur, dapat memahami hukum waris dalam Islam dan hikmahnya, dapat memahami hukum wasiat dan hikmahnya, dapat menerangkan dan mempraktekkan 13 macam hukum bacaan mad, dapat menjelaskan sejarah nuzulul

\footnotetext{
${ }^{32}$ Lihat "Himpunan Materi TKK PAI ...", h. vi.

${ }^{33}$ Lihat "Himpunan Materi TKK PAI ...", h. vii.

${ }^{34}$ Lihat "Himpunan Materi TKK PAI ...", h. vii.
}

Qur'an, maulid Nabi, Isra' Mi'raj, hifdzil Qur'an ayat pilihan, hifdzil Qur'an Juz 'Amma. ${ }^{35}$

Ketiga, Taqwa Character Building (TCB). TCB merupakan suatu sistem, cara atau metode yang dirancang untuk membangun karakter yang bertaqwa. Hal ini berlaku untuk semua kalangan, baik kepala sekolah, guru, dan terutama para siswa. ${ }^{36}$ Pelatihan dan praktek TCB melalui pengembangan 7 karakter, yaitu ikhlas, sabar, amanah, disiplin, peduli, cerdas, dan ihsan. Karakter ikhlas ditunjukkan dengan nilai-nilai sukarela, senang hati, public orientation, dan Allah satisvaction. Karakter sabar ditunjukkan dengan nilai-nilai kerja keras, mandiri, tangguh, dan mengendalikan diri. Karakter amanah ditunjukkan dengan nilai-nilai tanggung jawab, jujur, menepati janji, dan dapat dipercaya. Karakter disiplin ditunjukkan dengan nilai-nilai disiplin pada aturan Allah, pada diri sendiri, keluarga, sekolah, dan masyarakat. Karakter peduli ditunjukkan dengan nilai-nilai diri sendiri, keluarga, sekolah, masyarakat, dan alam semesta. Karakter cerdas ditunjukkan dengan nilai-nilai kreatif, inovatif, kritis, rajin, dan komunikatif. Karakter ihsan ditunjukkan dengan nilai-nilai ulet, unggul (do the best, be the best), hemat, dan menghargai prestasi. Masing-masing karakter beserta nilainilainya tersebut ditinjau dengan landasan AlQur'an, landasan Hadist, landasan keilmuan, diberikan pengertian, ditunjukkan tujuannya, manfaatnya, ciri-ciri/indikatornya, diberikan kisah teladan, ada brainstorming (apa yang dapat dilakukan agar mempunyai 7 sikap/ karakter tersebut, tindak lanjut (apa yang akan dilakukan setelah mengenal 7 sikap/karakter tersebut), dan evaluasi. Evaluasi dilakukan oleh wali asuh, wali kelas, guru mata pelajaran, dan orang tua di rumah. Jenis evaluasinya adalah pengamatan atau observasi sikap dan perilaku. Evaluasi dilakukan setiap minggu dan atau

\footnotetext{
${ }^{35}$ Lihat "Himpunan Materi TKK PAI ...", h. vii-viii.

${ }^{36}$ Dikutip dari "Workbook Taqwa Character Building Perguruan Darul Hikam: Membangun Siswa Berakhlak Berprestasi”, 2013, h. iv.
} 
pada event tertentu. Dan, pelaporan kepada orang tua dilaksanakan dalam satu semester bersamaan dengan hasil UTS dan pembagian raport. $^{37}$

Keempat, bimbingan ibadah. Salah satu aktivitas pendidikan pada SMU Darul Hikam ialah memberikan bimbingan kepada peserta didik untuk melaksanakan aktivitas ibadah (ibadah mahdoh) dan muamalah (ibadah ghoir mahdhoh). Hal ini dilakukan sebagai upaya untuk mencapai visi SMA Darul Hikam, yaitu "Menjadi Sekolah Islam Terbaik di Tingkat Jawa Barat Melalui Budaya (Jatidiri, Ciri Khas, dan Keunggulan) Berakhlak Berprestasi". Untuk mencapai visi tersebut telah dicanangkan 10 Budaya Berakhlak Berprestasi. Indikator pertamanya ialah rajin beribadah dan biasa shalat berjama'ah. ${ }^{38}$ Bimbingan ibadah tersebut dipandu dengan buku "Bimbingan Ibadah Panduan Bagi Guru, Siswa, dan Orang Tua", yang mengurai tentang thoharoh, sholat, sholat sunnah, doa sehari-hari, shoum, zakat, pengurusan jenazah, haji dan umroh, dan ilmu faroidl (ilmu mawaris).

Kelima, mempertajam PAI Aqidah, Akhlaq, dan Ibadah. Keenam, asistensi kajian keIslaman.

\section{Pokok/Inti Pembelajaran PAI Terpadu}

Inti pembelajaran PAI terpadu di SMA Darul Hikam Bandung, yaitu: Pertama, adanya keterpaduan antara pemahaman dan implementasi. Kedua, mengembangkan pembiasaan pemeliharaan softskill melalui shalat dhuha, dzikir dan doa. Ketiga, pelatihan dan praktek kepedulian sosial (bakti sosial dan praktek Qurban). Keempat, research tema-tema pokok, seperti pengaruh shaum terhadap kesehatan, budaya makan wanita haid, trend buka shaum dengan bala-bala, penelitian

\footnotetext{
${ }^{37}$ Lihat "Workbook Taqwa Character Building ...", 2013.

${ }^{38}$ Dikutip dari "Bimbingan Ibadah Panduan Bagi Guru, Siswa dan Orang Tua”, Perguruan Darul Hikam Bandung, 2012, h. xvi.
}

"kenapa minum dan makan jangan sambil berdiri". ${ }^{39}$

\section{Strategi Pembelajaran PAI Terpadu}

Strategi pembelajaran PAI yang dikembangkan di SMA Darul Hikam merupakan terjemah dari pendekatan pembelajaran, di antaranya; Pertama menetapkan spesifikasi dan kualifikasi tujuan pembelajaran yakni perubahan profil perilaku dan pribadi peserta didik. Kedua, mempertimbangkan dan memilih sistem pendekatan pembelajaran yang dipandang paling efektif. Ketiga, mempertimbangkan dan menetapkan langkah-langkah atau prosedur, metode dan teknik pembelajaran. Keempat, menetapkan norma-norma dan batas minimum ukuran keberhasilan atau kriteria dan ukuran baku keberhasilan. ${ }^{40}$

\section{Pendekatan dan Metode Pembelajaran PAI Terpadu}

Pendekatan pembelajaran PAI di SMA Darul Hikam dilakukan melalui student centered approach (pendekatan yang berpusat pada siswa), dalam kata lain student oriented. Siswa diberikan stimulus untuk bisa mengembangkan sendiri masalah dan pemecahannya dengan harapan melatih kemandirian sehingga pada gilirannya bisa menemukan sendiri jawaban dari setiap persoalan. ${ }^{41}$

Metode pembelajaran PAI terpadu yang digunakan di SMA Darul Hikam merupakan implementasi dari strategi pembelajaran, di antaranya: (1) ceramah; (2) demonstrasi; (3) diskusi; (4) simulasi; (5) laboratorium; (6) pengalaman lapangan; (7) brainstorming; (8) debat, (9) simposium; (10) unjuk kerja dan sebagainya. ${ }^{42}$

\footnotetext{
${ }^{39}$ Wawancara dengan Kepala Sekolah, 26 September 2013; Wawancara dengan Guru Pendidikan Agama Islam, 26 September 2013.

${ }^{40}$ Wawancara dengan Kepala Sekolah, 26 September 2013.

${ }^{41}$ Wawancara dengan Kepala Sekolah, 26 September 2013.

${ }^{42}$ Wawancara dengan Kepala Sekolah, 26 September 2013; Wawancara dengan Guru Pendidikan Agama Islam, 26 September 2013.
} 


\section{Penilaian dan Evaluasi PAI Terpadu}

Berkenaan dengan model penilaian dan evaluasi yang dilakukan oleh SMA Darul Hikam setidaknya ada 2 hal yang menjadi titik tolak penilaian. Pertama, model penilaian interaksi sosial, seperti pengamatan sikap dan tingkah laku siswa dengan siswa, siswa dengan guru, siswa dengan orangtua serta lingkungan.Kedua, model penilaian pengolahan informasi yang komperhensif. Model penilaian ini didasarkan pada data tertulis (hasil ulangan, ujian, unjuk kerja, tugas, laporan afeksi dari seluruh guru, wali kelas, psikolog dan BK). ${ }^{43}$

Adapun keterlibatan civitas sekolah, orang tua, siswa, majelis sekolah, masyarakat, dan pemerintah dilakukan secara sinergi melalui berbagai pola, di antaranya:44

1. Melalui pelatihan, seminar, simposium, MGMP, IHT (in house training) yang melibatkan unsur pemerintah dalam hal ini DIKNAS dan KEMENAG.

2. Informasi yang kontinyu kepada orangtua melalui wali asuh, seperti laporan berkala tentang perkembangan siswa (akademik dan sikap), UTS, UAS, UKK.

3. Musyawarah program kerja sekolah yang melibatkan komite sekolah, orang tua siswa dan stakeholder.

4. Interaksi masyarakat sekitar melalui peran serta siswa dalam kepedulian lingkungan danbantuan sosialyang diimplementasikan lewat momen pengelolaan hewan qurban, pembagian sembako pada event tertentu, bina desa (student work camp), buka bersama dengan kaum dhuafa, pembagian ZIS di bulan Ramadhan dan lain-lain.

\footnotetext{
${ }^{43}$ Wawancara dengan Kepala Sekolah, 26 September 2013; Wawancara dengan Guru Pendidikan Agama Islam, 26 September 2013.

${ }^{44}$ Wawancara dengan Kepala Sekolah, 26 September 2013; Wawancara dengan Guru Pendidikan Agama Islam, 26 September 2013.
}

\section{Model Pembelajaran PAI sebuah Analisis}

Implementasi pembelajaran PAI terpadu di SMA Darul Hikam terlihat jelas pada kurikulum khas (kurhas) pendidikan karakter dengan mengembangkan 7 nilai (ikhlas, sabar, amanah, disiplin, peduli, cerdas, dan ihsan) melalui Taqwa Character Building (ТCB) sebagaimana disinggung di atas. TCB ini sejalan dengan falsafah dan visi yang dibangun oleh SMA Darul Hikam. Lebih dari itu, TCB juga selaras dengan tujuan pendidikan nasional.

Dalam UU Nomor 20 Tahun 2003 tentang Sistem Pendidikan Nasional, Pasal 3, disebutkan bahwa tujuan pendidikan nasional adalah ingin menghasilkan manusia Indonesia seutuhnya, yaitu manusia yang beriman dan bertakwa kepada Tuhan Yang Maha Esa, berakhlak mulia, sehat, berilmu, cakap, kreatif, mandiri, dan menjadi warga negara yang demokratis serta bertanggung jawab. Tujuan ideal ini diwujudkan oleh SMA Darul Hikam melalui pelatihan dan praktek TCB.

Jika selama ini masih ada kegelisahan di berbagai kalangan masyarakat terkait dengan kondisi pendidikan nasional di tanah air karena masih terjadinya dikotomi antara pendidikan agama dengan pendidikan umum dan masih adanya ketidakseimbangan antara ranah kognitif, afektif, dan psikomotorik, Maka di SMA Darul Hikam berbagai persoalan tersebut dipecahkan dengan pengintegrasian pendidikan agama ke dalam sistem pendidikan sekolah melalui TCB tersebut. Melalui TCB itu SMA Darul Hikam tampaknya ingin memberikan jawaban terhadap kekurangan yang masih terjadi pada sekolah-sekolah pada umumnya yang masih mendikotomikan antara pendidikan agama dengan pendidikan umum, terlalu menekankan pada ranah kognitif dalam proses pembelajaran serta masih kurang optimalnya pembentukan peserta didik yang berwawasan iptek dan imtak. Itu sebabnya, SMA Darul Hikam mengembangkan 7 (tujuh) nilai karakter taqwa/ TCB yang diimplementasikan melalui internalisasi dalam semua mata pelajaran, mata pelajaran khas, 
dan kegiatan kesiswaan. Internalisasi 7 nilai dalam semua mata pelajaran dimaksudkan agar 7 nilai TCB tersebut terwujud dalam aktivitas pembelajaran sehingga peserta didik tidak semata-mata mengejar prestasi akademik, tetapi juga menjadi orang yang bertaqwa yang mengimplementasikan nilai-nilai tersebut dalam kehidupan sehari-hari.

Internalisasi 7 nilai dalam mata pelajaran khas (PAI [PAI (Diknas), Al-Qur'an, Mentoring, TKK), ICT, dan bahasa (conversation [Inggris] dan muhadastah [Arab]) juga dimaksudkan agar 7 nilai TCB tersebut tertanam dalam aktivitas pembelajaran sehingga peserta didik tidak hanya mencapai keunggulan dalam bidang PAI, ICT, dan bahasa, tetapi juga menjadi manusia berakhlak yang mengamalkan 7 nilai tersebut. Demikian juga internalisasi 7 nilai dalam kegiatan kesiswaan melalui 5 pilar kegiatan kesiswaan (SDM [siswa], wawasan dan motivasi, kepedulian, bakat minat, dan prestasi prestisius), dimaksudkan agar 7 nilai tersebut tertanam dalam kegiatan kesiswaan sehingga mereka mampu mengembangkan soft skill. Untuk menghasilkan peserta didik yang berimana dan bertaqwa, berakhlak mulia, sehat, berilmu, cakap, kreatif, mandiri, dan warga negara yang demokratis serta bertanggung jawab sebagai tujuan pendidikan nasional bukanlah pekerjaan mudah. Diperlukan sistem, cara atau metoda untuk membumikan hal tersebut. SMA Darul Hikam melalu pengembangan TCB tersebut berupaya untuk mewujudkan tujuan pendidikan nasional tersebut.

Dengan Taqwa Character Building (TCB), 7 nilai/karakter yaitu ikhlas, sabar, amanah, disiplin, peduli, cerdas, dan amanah tertaman dalam diri kepala sekolah, guru, dan khususnya siswa yang kemudian menjadi sikap dan perilaku dalam kehidupan seharihari. Melalaui TCB 7 nilai/karakter taqwa diupayakan menjadi sikap dan perilaku dalam kehidupan, baik di sekolah maupun di rumah. Karena itu, karakter orang yang ikhlas harus menunjunjung tinggi nilai-nilai sukarela, senang hati, public orientation, dan Allah satisvaction. Karakter orang yang sabar harus mengamalkan nilai-nilai kerja keras, mandiri, tangguh, dan mengendalikan diri. Karakter orang yang amanah harus mencerminkan nilai-nilai tanggung jawab, jujur, menepati janji, dan dapat dipercaya. Karakter orang yang disiplin harus menunjukkan nilai-nilai disiplin pada aturan Allah, pada diri sendiri, keluarga, sekolah, dan masyarakat. Karakter orang yang peduli harus menjunjung tinggi nilai-nilai diri sendiri, keluarga, sekolah, masyarakat, dan alam semesta. Karakter orang yang cerdas harus berpegang teguh pada nilai-nilai kreatif, inovatif, kritis, rajin, dan komunikatif. Karakter orang yang ihsan harus menunjukkan nilai-nilai ulet, unggul (do the best, be the best), hemat, dan menghargai prestasi.

Semua nilai yang dikembangkan tersebut bersumber pada Al-Qur'an dan Hadist yang diinternalisasikan ke dalam proses pembelajaran, baik internalisasi melalui semua mata pelajaran, mata pelajaran khas, maupun kegiatan kesiswaan sehingga pada gilirannya 7 nilai/karakter taqwa tersebut diharapkan menjadi sikap dan perilaku peserta didik dalam kehidupan sehari-hari.

\section{PENUTUP}

\section{Kesimpulan}

1. SMA Darul Hikam merupakan Sekolah Islam Terpadu yang mengintegrasikan nilai-nilai ajaran Islam ke dalam struktur kurikulum yang memadukan antara pemahaman dan implementasi dengan pendekatan pembelajaran PAIKEM (Pembelajaran Aktif, Inovatif, Kreatif, Efektif dan Menyenangkan) yang efektif, efisien, dan menyenangkan serta melibatkan civitas sekolah, orang tua, siswa, majelis sekolah, masyarakat.

2. Pembelajaran PAI terpadu diimpelemtasikan dalam kurhas (kurikulum khas) pendidikan karakter melalui Taqwa Character Building (TCB) dengan mengem- 
bangkan 7 nilai/karakter taqwa yang diimplementasikan dalam semua mata pelajaran, mata pelajarankhas, dankegiatan kesiswaan secara berkesinambungan.

\section{Rekomendasi}

Penelitian ini merekomendasikan agar Taqwa Character Building (TCB) SMA Darul Hikam menjadi model pengembangan bagi penyelenggaraan pendidikan agama terintegrasi dalam sistem pendidikan sekolah (Sekolah Islam Terpadu).

\section{Sumber Bacaan}

Aminuddin (1994): Pembelajaran Terpadu sebagai Bentuk Penerapan Kurikulum 1994 Mata Pelajaran Bahasa dan Sastra Indonesia, FPBS IKIP Malang

Konsep dasar dan Model-model Pembelajaran Terpadu (2013): anything-go-anything. blogspot.com/2013/11/konsep-dasar dan model-model html.
Barbara Clark (1983): Integrative Education, New York, Publishing House

Nandang Koswara (2011): Himpunan Materi TKK PAI: Tes Kecakapan Khusus Pendidikan Agama Islam, SMA Darul Hikam Bandung

Profil Yayasan Darul Hikam (2013): Yayasan Darul Hikam Bandung

Program Kerja SMA Darul Hikam Bandung (2013)

Sanusi, S. (1997): Integrasi Umat Islam, PT. Iqomatuddin, Bandung

Undang-undang Sistem Pendidikan Nasional No. 20 Tahun 2003, Sinar Grafika Indonesia-- 